\title{
Public procurement as an object of analysis in the context of reforming the system of public finance management
}

\begin{abstract}
The theoretical framework of public procurement through the definition of the concept of «ublic procurement»is analyzed, the role of analysis in the public finance management system, the principles of analysis of public procurement and its functions are studied. The article offers to interpret the public procurement as a component of public financial management system that constitutes a standardized mechanism of financial and economic relations between the government and business entities on the implementation of the state order for the goods, services, works on the principles of fair competition among participants, maximum economy and efficiency, the targeted use of budget funds, openness and transparency at all stages of procurement, equality of participants, objective and impartial evaluation of tender proposals, prevention of corruption actions and abuses to achieve the goals of state social and economic policies to meet public needs. The system of analysis principles of public procurement is reasonably presented: accuracy; completeness; adequacy of information; consistency; relevance; usability; specificity; complexity; consistency; regularity; objectivity; efficiency; economic feasibility; comparativeness; scientificity. The functions of the analysis of public procurement are the following: informative, control, evaluative and diagnostic, search, prognostic, protective, scientific and cognitive. The basic tools will make it possible to build a scientifically based mechanism for the analysis of public procurement.
\end{abstract}

Keywords: system of public financial management; public procurement; public procurement analysis; principles of analysis of public procurement; the analysis functions of the public procurement.

Urgency of the research. The reform of the public financial management system (hereinafter - PFMS), which in a general sense is an interrelated set of measures, instruments, as well as financial institutions that ensure the stable and effective functioning of the state financial system as a whole and its individual levels, contributing to the solution of state and regional/local social problems and tasks, as well as the development of the real sector of the economy, has lasted for more than ten years [1-6]. Significant achievements that have occurred during this time can be identified in the following areas $[5,6]$ : the system of public procurement; the system of independent external financial control; the tax system; the system of public investment management; ensuring public access to information on budget issues $[5,6]$. It should be noted that the first direction received not only a new content (the adoption of the Law of Ukraine «On public procurement» in order to approximate the legislation and standards of the EU, a significant reduction in cases that are not subject to competitive procedures, and the introduction of mandatory electronic procurement), but also rebranding as «public procurement» [7]. However, despite the making much headway towards the development of the subsystem of PFMS, certain regulations of exogenous (external) and endogenous (internal) influence on the public procurement system remained not fully decisive, as a justification and formation of the mechanism for the analysis of the latter.

Actual scientific researches and issues analysis the author relies on. The study of public procurement as a subsystem of PFMS was carried out at different times by such foreign and domestic scientists as S. Avdasheva, L. Alekseienko, V. Bazylevych, D. Bos, O. Vasylyk, H. Davoodi, S. Evenet, J. Deltas, M. Zvieriakov, J. Laffont, I. Kniazeva, J. MacMillan, P. Mauro, V. Melnykov, V. Osetskyi, O. Rozhko, O. Soudri, J. Stiglitz, J. Tirole, B. Heckman and others. Despite significant advances in economic research, analysis rarely extrapolates on public procurement (it is worth noting the single but very informative work of Professor Parasii-Verhunenko I. M. «The analysis of public procurement: methodological and practical aspects» (2017) [8]. A monograph and a thesis for a Doctor's of Economics degree of M.S. Pysmenna have become determinative in this field. The author presents the following innovations [9, 10]: «the social and economic prerequisites for development of public procurement system, as a guarantee of rational spending of public funds have been determined; the evolution of a legal framework for public procurement as control and analytical environment is studied; the principles of procurement procedures for public funds are identified and the variety of procurement on the basis of criterial assessments of the interaction of customers and participants of tender procedures is characterized; the tools of implementation of public procurement based on international regulatory approaches regulation of their conduct for the formation of information databases for monitoring and analysis are summarized; parameters for the evaluation of potential suppliers, and the stages of public procurement procedures with the aim of identifying controlled objects of public 
procurement are analyzed; the theoretical basis of the implementation of target use of budgetary funds in the public procurement process with the aim of conceptualizing the direction of methods of analysis is formed; quantitative and cost indicators of procurement procedures are constructed and methodological tools for evaluating the effectiveness of public procurement on the basis of implementation of international approaches of domestic practice are developed; accounting analytics of public procurement in terms of information technology is improved; risk-based approach in the methodology of the state audit of public procurement in electronic environment is improved; the theoretical and methodological bases of realization of paradigmatic approach to control and audit in the sphere of state (public) procurement; the analytical toolkit for selection criterion of the most economically advantageous procurement is developed; organizational and methodical principles of monitoring of public procurement as an integral part of public audit are enhanced». In justice to the weight and importance of the author's achievements, it should be noted that the analysis of the presented regulations indicates the need for further elaboration of theoretical and practical positions of the analysis of public procurement.

The aim of the research is to study, substantiate and form the theoretical basis for the analysis of public procurement as a part of the public financial management system.

The statement of basic materials. In the most generalized form, management is the activity of the subject manifested in a purposeful, organizing impact on the object of management, in order to bring the latter to the desired state for the subject. The management system is a single entity that exists and develops through the interaction of its components.

One of the founders of management theory Henri Fayol (1841-1825) identified five functions: planning, organizing, management, coordination and control [11, p. 40]. The management principles of Henri Fayol can be presented as follows [12, p. 30, 48]:

- division of labor, i.e. reassignment to employees some individual operations and, as a consequence, increasing productivity, due to the fact that the staff is able to focus their attention.

- power and responsibility, i.e. the right to give orders must be balanced with responsibility for their consequences.

- discipline, i.e. the need to comply with the rules established within the organization. In order to maintain discipline, it is necessary to have managers at all levels capable of applying adequate sanctions to violators of order.

- undivided authority, i.e. each employee reports only to one manager and receives orders only from him.

- unity of action, i.e. a group of employees should work using the same procedure aimed at achieving one goal.

- subordination of interests, i.e. the interests of an employee or a group of employees should not be placed above the interests of the organization.

- reward, i.e. a fair way to encourage employees.

- centralization, i.e. a natural order within an organization that has a control center. The degree of centralization depends on each case.

- hierarchy is an organizational hierarchy that should not be broken, but that should be reduced as far as possible to avoid harm.

- order, that is a specific place for each person and each person is in the right place.

- fairness, i.e. respect and justice of administration to subordinates, the combination of goodwill and equity.

- continuity of personnel, i.e. staff turnover weakens the organization and is a consequence of poor management.

- initiative, i.e. providing opportunities for personal initiative to employees.

- corporate spirit - solidarity of employees, unity of power.

It is noteworthy that the set of management principles since their publication in 1916 in the" General industrial administration" have not been changed, while the management function was motivated to expand during a century (the concept developed by V. Khil (1968)): planning, organization, coordination, promotion, regulation and control [25, p. 43;26, p. 142]. Recent achievements of domestic scientists suggest the expediency of allocating only four functions: planning, organization, motivation and control, despite the fact that these functions are implemented in any management process (coordination and regulation functions are actually components of the functions of planning, organization, motivation and control) [13, p.36].

However, modern scientists and economists are increasingly inclined to the need to distinguish among management functions also the function of analysis. Thus, the well-known academic economists S.S. Moshenskyi, O.V. Oliinyk reasonably insist on such a position, motivating the loyalty to the fact that «... the analysis is carried out at all levels of management, in all departments of the economic entity and components of the economy, it is a prerequisite for individual management functions; the analysis is based on a single methodological basis, which makes it possible to form general recommendations for the organization and conducting analytical work, which, in its turn, can serve as a basis for comparison and analytical generalizations at the macroeconomic level» [14, p. 45]. Another well-known academic economist, Sheremet O.D., notes that economic analysis is an objectively necessary 
element of enterprise activity management, which helps to determine the essence of economic processes, assess the financial situation, identify reserves and production potential, and make decisions for planning and management $[15$, p.10]. Well-known academic economists V.V. Kovalev, O.N. Volkova clearly recognize the analysis among the control functions [16, p. 13]. Professor Savytska H.V. believes that «analysis of economic activity is an important economic science, which occupies a central position among the functions of the management system» and provides scientific decision-making [17, p.10].

Thus, the above makes it possible to argue about the need to allocate among the functions of the public finance management system the functions of analysis.

Traditionally, the main elements of the management system include:

- the subject of management, that is, the source of control influence, the one who manages, performs the functions of management and affects the object in order to transfer it to a new state;

- the object of control, i.e. something the control influence of the subject is directed at; that is functioning under this influence;

- the control action, that is, a set of targeted and organizing teams, events, techniques, methods by which exposure is performed on the object and real change is achieved;

- feedbacks, that is, information for the subject about the effectiveness of the control action and changes in the object.

According to the earlier regulation for the PFMS reform, full control object is public procurement subjected to the functional effects through component analysis. Let us turn to the concept of "public procurement" in the context of the object sphere of analysis.

It should be noted that the concept of «public procurement» in the domestic regulatory field is recently officially enshrined through the Law of Ukraine «On public procurement», according to which the latter represents the acquisition of goods, works and services by the customer in the manner prescribed by the Law [18]. The presented definition should be considered weakly informative, and therefore requires clarification. Let us turn to the characteristics of public procurement presented in the specialized literature.

So, young scientists Kvach V.Yu., Afanasiiev H. V. argue that the implementation of the current tasks for which the state should purchase goods, services, should contribute to the achievement of the goals of the state social economic policy. With the help of such economic operations, which under certain conditions form a procurement relationship, the state ensures the implementation of its economic and social functions in all spheres of social life. Public procurement, which is based on an auction and an objective and independent approach to determining the winner, serves as a market mechanism for the effective use of budgetary funds. The implementation of public procurement procedures currently attracts considerable attention of scientists, since in the case of an effective system of transparent public procurement procedures, the adoption of honest, objective and non-discriminatory decisions by customers, the presence of anti-corruption programs, the increase in the economic, political and public spheres of the state becomes possible» [19, p.884].

Ovramets Yu.O. notes that public procurement of goods, works and services [7, p. 187-188] is the legal mechanism that makes possible the choice of the state in favor of the contractor on the most favorable market conditions; the necessary conditions for the implementation of such a task are impartial competitive process of procurement and selection of the winner based on predetermined criteria; the ultimate goal of such a mechanism, optimization of the suppliers on the principle of «economic feasibility» (i.e., full compliance with the eligibility criteria of the competition and the low cost of their goods, works, services; the mechanism of development of contractual relations "state-private sector" with the goal of solving social economic problems of the state and society, including relation to research, create and implement the latest technologies and developments, attracting thus the private sector to provide the society with all the necessary social services; economic tool to ensure the implementation of the constitutional functions of the state regarding the development and functioning of strategic sectors of the economy, national security, health, education, science, culture, physical culture and sports, the maintenance of order and the like.

In conclusion of his detailed study, Ovramets Yu. O. notes that «the full implementation of state functions and the normal functioning of society is impossible without the availability of public procurement» and presents the following features of public procurement (table.1); as a result, the author proposes to understand public procurement as «...institute of administrative law, which determines the process of implementation of the state order, which is the acquisition of public procurement of goods, works and services by the customer in the order of the most favorable market conditions in order to meet the public interest (public needs)» [7, p.188-189]. 
Characteristic features of public procurement ${ }^{1}$

\begin{tabular}{|l|l|}
\hline \multicolumn{1}{|c|}{ Feature } & \multicolumn{1}{c|}{ Characteristics of a feature } \\
\hline Regulatory compliance & $\begin{array}{l}\text { customers have the right to make purchases carried out exclusively in } \\
\text { the form and manner according to the legislation of Ukraine according } \\
\text { to the procedure of clearly expressed administrative nature }\end{array}$ \\
\hline Targeted use of funds & $\begin{array}{l}\text { purchases are carried out exclusively on the basis of budget } \\
\text { assignments and to perform socially significant tasks assigned to the } \\
\text { customer }\end{array}$ \\
\hline Competitive character & $\begin{array}{l}\text { procurement should be carried out on a competitive and transparent } \\
\text { basis without any discrimination }\end{array}$ \\
\hline Economic feasibility & $\begin{array}{l}\text { in order to ensure budget savings and prevent corruption, customers } \\
\text { are required to choose the one of the bidders who offered the lowest } \\
\text { price for their goods, works and services, with complete compliance } \\
\text { of the declared qualification criteria. }\end{array}$ \\
\hline Economic policy instrument & $\begin{array}{l}\text { through public procurement and commodity interventions, the state } \\
\text { can form the level of demand and supply in the national market of a } \\
\text { product. }\end{array}$ \\
\hline
\end{tabular}

Pappas S., studying the international experience of public procurement, comes to the conclusion that «...public procurement is a set of public relations arising in the process of implementation by the customer of public needs for goods, works and services for public funds in the manner prescribed by the legislation of Ukraine» [20, p.72].

Novakovets V.M. in his thesis proposes to consider public procurement (state procurement) as a specific instrument of financial and legal regulation of relations on formation, rational distribution and efficient use of public funds used in the implementation of public interest in the acquisition of goods, works and services for public funds [21, p. 72].

Soshnykov A.O. argues that the main purpose of the implementation of public procurement is to meet public needs [22, p. 224].

For the implementation of an integrated approach to the conceptual study of the selected object, we turn to the normative legal acts of the sphere of the PFMS.

Thus, the Strategy of development of the public Finance management system, where for the first time state/public procurement is defined by the element of the PFMS, provides for the development of this component to ensure the further formation of a unified structured system of public procurement on the principles of transparency, openness, non-discrimination and competition, the functioning of which will ensure the rational and effective use of public funds and meet the public needs for high-quality goods and services [2]. Also, this normative act establishes the potential strategic role of state/public procurement in the development of Ukraine as a whole and assistance of effective and efficient public administration, social responsibility and sustainable development in particular through the implementation of the principles of fair competition among the participants, maximum economy and efficiency, openness and transparency at all stages of procurement, equality of participants, objective and impartial evaluation of bids, prevention of corruption and abuse.

The strategies of reforming the system of public finance management in 2017-2020 appeal to public procurement, but do not give any of their characteristics, however, contain links to the Strategy of reforming the public procurement system («road map») [5]. This normative document notes that «one of the main functions of the state is the purchase of goods, works and services to meet the most important social needs, which is carried out on the basis of the rational use of public funds and the development of a competitive economy. Public procurement reform is related to political, legal, social, financial, institutional, ethical and technological tasks, the solution of which will contribute to the sustainable social and economic development of the state, the competitiveness of the economy and the dynamic integration of Ukraine into international markets, in particular into the EU common market...» [23].

The generalization of above mentioned characteristics allows to interpret the public procurement as a component of public financial management system that constitutes a standardized mechanism of financial and

1 is generalized on the basis of [7, p. 189] 
economic relations between the government and business entities on the implementation of the state order for the goods, services, works on the principles of fair competition among participants, maximum economy and efficiency, the targeted use of budget funds, openness and transparency at all stages of procurement, equality of participants, objective and impartial evaluation of tender proposals, prevention of corruption actions and abuses to achieve the goals of state social and economic policies to meet public needs.

For the further development of the theoretical foundations of public procurement analysis, the subject of the latter should be considered as the structure and content of information flows within the specified mechanism in the context of all stages. The main task of the analysis of public procurement is to assess its results, identify the factors of influence that led to the relevant results in the analyzed period, as well as planning and forecasting activities in the field of public procurement for the future. It is solved with the help of not only cost accounting data, but also operational and statistical data in different units of measurement.

Despite the classical approaches to the definition of requirements for the results of the economic analysis of activity [27-31], namely, they should be reliable, because it has a significant impact on decision-making; useful or sufficiently complete, that is, unambiguously characterize the event; essential and concise or relevant, or clearly correspond to the information request; adequate to the current state of the process or reliable; significant (substantial) in the sense that they potentially affect the decisions; presented in a user-friendly form, and taking into account the peculiarities of the public procurement mechanism within the framework of the PFMS that the authors propose the following composition of the principles of analysis of public procurement [14-17, 27-31]: reliability; completeness; sufficiency of information; compliance; significance; convenience; specificity; complexity; consistency; regularity; objectivity; efficiency; economic feasibility; comparability; scientificity.

The functions of the analysis of public procurement are the following: informative, control, evaluative and diagnostic, search, prognostic, protective, scientific and cognitive. The composition of the tasks of public procurement analysis is determined by the set of proposed functions. Due to the large number of existing tasks of economic analysis today (about 40 positions collectively for different sources of specialized literature), the development of problems of analysis of public procurement requires processing and submission to an individual publication.

Conclusions and prospects for further research. The development of the theoretical basis of the analysis of public procurement as an important element of the PFMS requires further continuation in order to finally form a sustainable scientific basis for the methods of such analysis. The construction of analytical mechanisms for public procurement, taking into account these theoretical positions will ensure their quality and practical effectiveness in time. The formation of an effective analytical support of an important element of the PFMS will increase its manageability and efficiency in general.

\section{Список використаної літератури:}

1. Угода про позику (Проект модернізації державних фінансів) між Україною та Міжнародним банком реконструкції та розвитку (25.03.2008) : ратифікована Законом України : від 24.09.2008 : N 591-VI / Міністерство фінансів України.

2. Про Стратегію розвитку системи управління державними фінансами : розпорядження Кабінету Міністрів України : станом на 1 серпня 2013 : N 774-p. / Верховна Рада України [Електронний ресурс]. - Режим доступу : http://zakon4.rada.gov.ua/laws/show/774-2013-p/print1360051017911272.

3. Про схвалення Концепції розвитку системи управління державними фінансами : розпорядження Кабінету Міністрів України : станом на 3 серпня 2012 : N 633-р / Верховна Рада України [Електронний ресурс]. Режим доступу : http://zakon4.rada.gov.ua/laws/show/633-2012p/print1360051017911272.

4. Про схвалення Стратегії модернізації системи управління державними фінансами : розпорядження Кабінету Міністрів України : станом на 17 жовтня 2007 : N 888-p / Верховна Рада Украйни [Електронний ресурс]. Режим доступу : http://zakon2.rada.gov.ua/laws/show/888-2007-p.

5. Про схвалення Стратегії реформування системи управління державними фінансами на 2017-2020 роки : розпорядження Кабінету Міністрів України : станом на 8 лютого 2017 : N 142-р / Верховна Рада України [Електронний ресурс]. - Режим доступу : http://zakon3.rada.gov.ua/laws/show/142-2017.

6. Свірко C.B. Сучасний розвиток системи управління державними фінансами України: обліковий сегмент в забезпеченні інноваційно-інвестиційного вектору спрямування / C.B. Свірко // Вісник ЖДТУ. Серія : Економічні науки. - Вип. 1 (83). - Житомир : ЖДТУ, 2018. - С. 56-65.

7. Оврамещь Ю.О. Поняття та сутність «публічних закупівель» в адміністративному праві України / Ю.О. Оврамець [Електронний ресурс]. - Режим доступу : http://journals.nubip.edu.ua/index.php/Pravo/article/viewFile/9261/8389.

8. Парасіи-Вергуненко I.M. Аналіз публічних закупівель: методичні та практичні аспекти / I.M. ПарасіиВергуненко // Наукові записки Національного університету «Острозька академія» : наук. журнал. Серія : Економіка. - Острог : Вид-во НаУОА, грудень 2017. - № 7 (35). - С. 65-71.

9. Письменна М.С. Державний аудит та аналіз публічних закупівель: теорія, методологія та практика : монографія / М.С. Письменна. - К. : ЦУЛ, 2017. - 452 с.

10. Письменна М.С. Методологія та організація аналізу та контролю закупівель за державні кошти : дис. ... д.е.н. : спец. 08.00.09 / М.С. Письменна ; Одеський національний економічний ун-т. - Одеса, 2018. - 503 с. 
11. Устенко Л.П. Менеджмент на комунальному підприємстві / Л.П. Устенко. - К. : Бравоглас, 2010. -80 с.

12. Веснин В.P. Основы менеджмента / В.Р. Веснин. - М. : Проспект, 2014. - 320 с.

13. Нечаюк Л.І. Готельно-ресторанний бізнес: менеджмент : навч. посібник / Л.І. Нечаюк, Н.О. Телеш. - К. : ЦУЛ, 2003. $-348 \mathrm{c}$.

14. Мошенський С.3. Економічний аналіз : підручник / С.3. Мошенський, О.В. Олійник ; за ред. Ф.Ф. Бутиния. Житомир : ПП Рута, 2007. - 704 с.

15. Шеремет А.Д. Комплексный анализ хозяйственной деятельности / А.Д. Шеремет. - М. : ИНФРА, 2006. - 415 с.

16. Ковалев В.В. Анализ хозяйственной деятельности предприятия / В.В. Ковалев, О.Н. Волкова - М. : ТК Велби, 2002. $-424 \mathrm{c}$.

17. Савицька Г.В. Економічний аналіз діяльності підприємства : навч. посібник / Г.В. Савицька . - 3-тє вид., випр. і доп . - К. : Знання, 2007. - 668 с.

18. Про публічні закупівлі : закон України : від 25.12.2015 / Верховна Рада України // Відомості Верховної Ради. 2016. - № 9, Ст. 89.

19. Квач В.Ю. Загальнотеоретичні положення про публічні закупівлі: поняття та призначення / В.Ю. Квач, P.B. Афанасієв // Науковий журнал ХДУ «Молодий вчений». - Херсон : ТОВ «Видавничий дім «Гельветика», листопад 2017. - № 11 (51). - 1361 с.

20. Паппас C. Політика СС у сфері державних закупівель / С.Папnас. - К., 2005. - 121 с.

21. Новаковець В.М. Фінансово-правовий механізм регулювання державних закупівель : дис. ... к.ю.н. : спец. 12.00 .07 - адміністративне право і процес; фінансове право; інформаційне право / В.М. Новаковець / Національна академія внутрішніх справ. - К., 2012. - 252 с.

22. Сошников А.O. Теоретичні засади здійснення публічних закупівель / А.O. Сошников // Часопис Київського університету права. - 2015. - № 3. - С. 221-226.

23. Про схвалення Стратегії реформування системи публічних закупівель («дорожня карта») : розпорядження Кабінету Міністрів України : станом на 24 лютого 2016 : N 175-p. / Верховна Рада України [Електронний pecypc]. - Режим доступу : http://zakon3.rada.gov.ua/laws/show/142-2017.

24. Галенко С.Н. Аналіз господарської діяльності комунальних підприємств: методика та організація : дис. ... к.е.н. : спец. 08.00.09 / С.Н. Галенко ; Київський національний економічний ун-т. - К., 2012. - 189 с.

25. Світлична Ю.В. Корпоративна форма управління як елемент антикризової стратегії комунального господарства / Ю.В. Світлична // Економіка будівництва і міського господарства. - 2005. - № 1. - С. 41-48.

26. Сачиновський M.I. Регіональна економіка / M.I. Сациновський. - К. : Аскери, 2003. - 560 с.

27. Галенко С.M. Формування та приорітетність функцій аналізу господарської діяльності комунального підприємства / С.М. Галенко // Стратегія розвитку столиць світу : зб-к Матеріалів міжнародної науковопрактичної конференції, 28 лист. 2010 р., Київ. - К. : КМДУ «НДІРоМ», 2010. - С. 97-102.

28. Галенко С.M. Завдання та принципи аналізу господарської діяльності комунальних підприємств / C.M. Галенко // Роль і місце бухгалтерського обліку, контролю і аналізу в розвитку економічної науки та практики : зб-к Матеріалів міжнародної науково-практичної конференції, 14 травня 2010 р., Київ. - К. : КНЕУ, 2010. - С. 252-255.

29. Економічний аналіз : навч. посібник / М.А. Болюх, В.З. Бурчевський, М.І. Горбаток, А.П. Заросило, В.М. Івахненко ; за ред. М.Г. Чумаченко / Київський національний економічний ун-т. - К. : КНЕУ, 2001. - 540 с.

30. Мних Є.B. Економічний аналіз діяльності підприємства : підручник / С.B. Мних ; Київський національний торговельно-економічний ун-т. - К., 2008. - 513 с.

31. Лазаришина І.Д. Економічний аналіз в Україні: історія, методологія, практика / І.Д. Лазаришина. - Рівне : НУВГП, 2005. - $369 \mathrm{c}$.

32. Свірко С.В. Бухгалтерський облік в бюджетних установах України: методологія і організація : дис. ... д.е.н. : спец. 08.06.04 / С.В. Свірко / Київський національний економічний ун-т ім. Вадима Гетьмана. - К., 2006. -520 с.

33. Бухгалтерський облік та фінансовий контроль - складові інформаційного підгрунтя євроінтеграційних процесів в Україні : у 4 т. / Редкол. : М.Я. Азаров (голова) та ін. - К. : НДФІ, 2007. - Т. 3 : Бухгалтерський облік і звітність установ та організацій державного сектору в Україні: напрями та перспективи розвитку / T.I. Єфименко, С.О. Левицька, Л.Г. Ловінська, С.В. Свірко. - 2007. - 552 с.

34. Інформаційне забезпечення управління держаними фінансами : у 2-х т. / за ред. Ф.О. Ярошенка. - К. : ДННУ «Акад. фін. управління», 2010. - Т. I : Стандартизація бюджетного обліку як інструмент модернізації державних фінансів України / T.I. Єфіменко, Л.Г. Ловінська, С.В. Свірко та ін. - 2010. - 226 с.

35. Державний бюджет і бюджетна стратегія 2012-2014: стабілізація та сталий розвиток в умовах реформування економіки України : у 4 т. / ДННУ «Акад. фін. управління» ; за ред. Ф.О. Ярошенка. - К., 2011. - Т. 2 : Бюджетна стратегія і Державний бюджет 2012: збалансованість, прозорість, реалістичність. - 2011. - 882 с. C. $744-764$.

36. Бухгалтерський облік і контроль державного сектору в умовах модернізації управління державними фінансами : у 2 т. / за ред. Л.Г. Ловинської. - К. : ДННУ «Акад. фін. управління», 2013. - Т. 1 : Реформування бухгалтерського обліку в державному секторі відповідно до міжнародних стандартів / Л.Г. Ловінська, H.I. Сушко, С.В. Свірко та ін. $-2013 .-568$ с.

\section{References:}

1. Ministerstvo finansiv Ukrai'ny (2008), Ugoda pro pozyku (Proekt modernizaciï derzhavnyh finansiv) mizh Ukraïnoju ta Mizhnarodnym bankom rekonstrukciï ta rozvytku, vid 25 bereznja, ratyfikovana Zakonom Ukraïny, vid 24 veresnja, N 591-VI. 
2. Verhovna Rada Ukraïny (2013), «Pro Strategiju rozvytku systemy upravlinnja derzhavnymy finansamy», rozporjadzhennja Kabinetu Ministriv Ukraïny, stanom na 1 serpnja, N 774-r., [On-line], available at: http://zakon4.rada.gov.ua/laws/show/774-2013-r/print1360051017911272

3. Verhovna Rada Ukraïny (2012), «Pro shvalennja Koncepciï rozvytku systemy upravlinnja derzhavnymy finansamy», rozporjadzhennja Kabinetu Ministriv Ukraïny, stanom na 3 serpnja, N 633-r., [On-line], available at: http://zakon4.rada.gov.ua/laws/show/633-2012r/print1360051017911272

4. Verhovna Rada Ukraïny (2007), «Pro shvalennja Strategiï modernizaciï systemy upravlinnja derzhavnymy finansamy», rozporjadzhennja Kabinetu Ministriv Ukraïny, stanom na 17 zhovtnja, N 888-r., [On-line], available at: http://zakon2.rada.gov.ua/laws/show/888-2007-r

5. Verhovna Rada Ukraïny (2017), «Pro shvalennja Strategiï reformuvannja systemy upravlinnja derzhavnymy finansamy na 2017-2020 roky», rozporjadzhennja Kabinetu Ministriv Ukraïny, stanom na 8 ljutogo, N 142-r., [On-line], available at: http://zakon3.rada.gov.ua/laws/show/142-2017

6. Svirko, S.V. (2018), «Suchasnyj rozvytok systemy upravlinnja derzhavnymy finansamy Ukrai'ny: oblikovyj segment v zabezpechenni innovacijno-investycijnogo vektoru sprjamuvannja», Visnyk ZhDTU, Serija Ekonomichni nauky, Vol. 1 (83), ZhDTU, Zhytomyr, pp. 56-65.

7. Ovramec', Ju.O., «Ponjattja ta sutnist' «publichnyh zakupivel'» v administratyvnomu pravi Ukrai'ny», [On-line], available at: http://journals.nubip.edu.ua/index.php/Pravo/article/viewFile/9261/8389

8. Parasiy̆-Vergunenko, I.M. (2017), «Analiz publichnyh zakupivel': metodychni ta praktychni aspekty», Naukovi zapysky Nacional'nogo universytetu «Ostroz'ka akademija», nauk. Zhurnal, Serija Ekonomika, vid grudnja, No. 7 (35), Vyd-vo NaUOA, Ostrog, pp. 65-71.

9. Pys'menna, M.S. (2017), Derzhavnyy audyt ta analiz publichnyh zakupivel': teorija, metodologija ta praktyka, monografija, CUL, Kyi'v, $452 \mathrm{p}$.

10. Pys'menna, M.S. (2018), Metodologija ta organizacija analizu ta kontrolju zakupivel' za derzhavni koshty, Dyss. of d.e.n., spec. 08.00.09, Odes'kyj nacional'nyj ekonomichnyj un-t, Odesa, 503 p.

11. Ustenko, L.P. (2010), Menedzhment na komunal'nomu pidpryjemstvi, Bravoglas, Kyi'v, 80 p.

12. Vesnin, V.R. (2014), Osnovy menedzhmenta, Prospekt, Moskva, 320 p.

13. Nechajuk, L.I. and Telesh, N.O. (2003), Gotel'no-restorannyj biznes: menedzhment, CUL, Kyi'v, 348 p.

14. Moshens'kyj, S.Z. and Olijnyk, O.V. (2007), Ekonomichnyj analiz, in Butynec', F.F. (ed.), PP Ruta, Zhytomyr, 704 p.

15. Sheremet, A.D. (2006), Kompleksnyj analiz hozjajstvennoj dejatel'nosti, INFRA, Moskva, 415 p.

16. Kovalev, V.V. and Volkova, O.N. (2002), Analiz hozjajstvennoj dejatel'nosti predprijatija, TK Velbi, Moskva, 424 p.

17. Savyc'ka, G.V. (2007), Ekonomichnyj analiz dijal'nosti pidpryjemstva, $3^{\text {rd }}$ ed., vypr. i dop., Znannja, Kyi'v, 668 p.

18. Verhovna Rada Ukraïny (2016), «Pro publichni zakupivli», zakon Ukraïny, stanom na 25 grudnja, Vidomosti Verhovnoï Rady, No. 9, St. 89.

19. Kvach, V.Ju. and Afanasijev, R.V. (2017), «Zagal'noteoretychni polozhennja pro publichni zakupivli: ponjattja ta pryznachennja», Naukovyj zhurnal HDU «Molodyy vchenyy»», vid lystopada, No. 11 (51), TOV «Vydavnychyy̆ dim «Gel'vetyka», Herson, 1361 p.

20. Pappas, S. (2005), Polityka JeS u sferi derzhavnyh zakupivel', Kyi'v, 121 p.

21. Novakovec', V.M. (2012), Finansovo-pravovyy̆ mehanizm reguljuvannja derzhavnyh zakupivel', Dyss. of k.ju.n., spec. 12.00.07 administratyvne pravo i proces; finansove pravo; informaciy̆ne pravo, Nacional'na akademija vnutrishnih sprav, Kyi'v, 252 p.

22. Soshnykov, A.O. (2015), «Teoretychni zasady zdijsnennja publichnyh zakupivel'», Chasopys Kyi'vs'kogo universytetu prava, No. 3, pp. 221-226.

23. Verhovna Rada Ukräny (2017), «Pro shvalennja Strategii' reformuvannja systemy publichnyh zakupivel' («dorozhnja karta»)», rozporjadzhennja Kabinetu Ministriv Ukraïny, stanom na 24 ljutogo, N 175-r., [On-line], available at: http://zakon3.rada.gov.ua/laws/show/142-2017

24. Galenko, S.N. (2012), Analiz gospodars'koi' dijal'nosti komunal'nyh pidpryjemstv: metodyka ta organizacija, Dyss. of k.e.n., spec. 08.00.09, Kyi'vs'kyj nacional'nyj ekonomichnyj un-t, Kyi'v, 189 p.

25. Svitlychna, Ju.V. (2005), «Korporatyvna forma upravlinnja jak element antykryzovoi' strategii' komunal'nogo gospodarstva», Ekonomika budivnyctva i mis'kogo gospodarstva, No. 1, pp. 41-48.

26. Sacynovs'kyj, M.I. (2003), Regional'na ekonomika, Askery, Kyi'v, 560 p.

27. Galenko, S.M. (2010), «Formuvannja ta pryoritetnist' funkcij analizu gospodars'koi' dijal'nosti komunal'nogo pidpryjemstva», Strategija rozvytku stolyc' svitu, zb-k Materialiv mizhnarodnoi' naukovo-praktychnoi' konferencii', vid 28 lyst., KMDU «NDIRoM», Kyi'v, pp. 97-102.

28. Galenko, S.M. (2010), «Zavdannja ta pryncypy analizu gospodars'koi' dijal'nosti komunal'nyh pidpryjemstv», Rol' $i$ misce buhgalters'kogo obliku, kontrolju $i$ analizu $v$ rozvytku ekonomichnoi' nauky ta praktyky, zb-k Materialiv mizhnarodnoi' naukovo-praktychnoi' konferencii', vid 14 travnja, KNEU, Kyi'v, pp. 252-255.

29. Boljuh, M.A., Burchevs'kyj, V.Z., Gorbatok, M.I., Zarosylo, A.P. and Ivahnenko, V.M. (2001), Ekonomichnyj analiz, in Chumachenko, M.G. (ed.), Kyi'vs'kyj nacional'nyj ekonomichnyj un-t, KNEU, Kyi'v, 540 p.

30. Mnyh, Je.V. (2008), Ekonomichnyj analiz dijal'nosti pidpryjemstva, Kyi'vs'kyj nacional'nyj torgovel'no-ekonomichnyj un-t, Kyi'v, $513 \mathrm{p}$

31. Lazaryshyna, I.D. (2005), Ekonomichnyj analiz v Ukrai'ni: istorija, metodologija, praktyka, NUVGP, Rivne, 369 p.

32. Svirko, S.V. (2006), Buhgalters'kyy̆ oblik v bjudzhetnyh ustanovah Ukrä̈n: metodologija i organizacija, Dyss. of d.e.n., spec. 08.06.04, Kyïvs'kyy̆ nacional'nyy̆ ekonomichnyy̆ un-t im. Vadyma Get'mana, Kyi'v, 520 p.

33. Azarov, M.Ja. (ed.) (2007), Buhgalters'kyj oblik ta finansovyj kontrol' - skladovi informacijnogo pidg'runtja jevrointegracijnyh procesiv v Ukrai'ni, in 4 parts, Jefymenko, T.I., Levyc'ka, S.O., Lovins'ka, L.G. and Svirko, S.V., 
Part 3 «Buhgalters'kyj oblik i zvitnist' ustanov ta organizacij derzhavnogo sektoru v Ukrai'ni: naprjamy ta perspektyvy rozvytku», NDFI, Kyi'v, 552 p.

34. Jefimenko, T.I., Lovins'ka, L.G., Svirko, S.V. and others (2010), Informacijne zabezpechennja upravlinnja derzhanymy finansamy, in 2 volumes, Vol. 1 «Standartyzacija bjudzhetnogo obliku jak instrument modernizacii' derzhavnyh finansiv Ukrai'ny», in Jaroshenko, F.O. (ed.), DNNU «Akad. fin. upravlinnja», Kyi'v, 226 p.

35. Jaroshenko, F.O. (ed.) (2011), Derzhavnyj bjudzhet i bjudzhetna strategija 2012-2014: stabilizacija ta stalyj rozvytok v umovah reformuvannja ekonomiky Ukrai'ny, in 4 volumes, Vol. 2 «Bjudzhetna strategija i Derzhavnyj bjudzhet 2012: zbalansovanist', prozorist', realistychnist'», DNNU «Akad. fin. upravlinnja», Kyi'v, 882 p., pp. 744-764.

36. Lovins'ka, L.G., Sushko, N.I., Svirko, S.V. and others (2013), Buhgalters'kyj oblik i kontrol' derzhavnogo sektoru v umovah modernizacii' upravlinnja derzhavnymy finansamy, in 2 volumes, in Lovins'ka, L.G. (ed.), Vol. 1 «Reformuvannja buhgalters'kogo obliku v derzhavnomu sektori vidpovidno do mizhnarodnyh standartiv», DNNU «Akad. fin. upravlinnja», Kyi'v, 568 p.

Грицишен Димитрій Олександрович - доктор економічних наук, професор, декан факультету публічного управління та права Житомирського державного технологічного університету.

Наукові інтереси:

- бухгалтерський облік в системі управління еколого-економічною безпекою підприємств.

Свірко Світлана Володимирівна - доктор економічних наук, професор, професор кафедри економічної безпеки, публічного управління та адміністрування Житомирського державного технологічного університету.

Наукові інтереси:

- теорія та методологія бухгалтерського обліку в секторі загального державного управління;

- методика та організація бухгалтерського обліку в секторі загального державного управління;

- система управління державними фінансами в цілому та в контексті ії облікового забезпечення зокрема;

- бюджетна система та бюджетний процес в умовах глобалізаційного розвитку.

Супрунова Ірина Валеріївна - кандидат економічних наук, доцент, докторант Житомирського державного технологічного університету.

Наукові інтереси:

- проблеми оцінки в бухгалтерському обліку;

- теорія, методологія та організація бухгалтерського обліку в секторі загального державного управління;

- економічний розвиток на регіональному та національному рівнях.

Стаття надійшла до редакції 10.09.2018. 